\title{
New Viewing of Blood Circulation in Human Body
}

\section{Telman Mammadov*}

Department of Hematology, Azerbaijan University, Baku, Azerbaijan

\section{Opinion}

It is known that blood circulation is very important for human organism. The blood, transport nourishments all of the tissues and as a result of the metabolism arising residues remove from organism these are very important function of blood. With these functions, blood is the reason of the some diseases. Nowadays during industrialization nourishments were critically liable thermal and chemical influences, these nourishments aren't dissolve for Organism. Therefore, nourishing things are collected difference place of body and prevent Organ to develop. All of these arguments show us that the blood and blood circulations are very important to learn because we can cure our illness.

Medicine and biology had two views for this problem till now. Blood was pumped all of the vessel by heart, the most recognized and were accepted in modern medicine without hesitation, this was first view and today nearly $90 \%$ clinics in the world are prefer to work this principle. Second view was belong Japan scientist Katsudzo Nishi. This principle means that the blood circulation motive power was capillary blood vessels. Capillary blood vessels sucked the blood and pumped the cells and removed metabolism residues. But this claim did not consider earnest from academic side.

To play a great role for the health, for cure of illnesses I noticed that had key reasons and I had been thinking about this. But finally I thought that both of the principles were wrong. My decision is which power dispense blood through body are not placed heart and capillary blood vessels. I think this power is placed in cells.

\section{I can explain my claim}

We can think that, in spring season we closed eyes and lying. We are quiet, we don't think about anything and don't pay attention anything, all of the nervous systems are working very quietly and our Organs work together then we stand up and walking in meadow. Suddenly we see a flower, the flower is very beautiful and we can't distract our eyes from the flower. We approach to the flower and stand in front of flower and watching it, its' color and petals are very beautiful. For a long time we are amazed for this flower, we are watching very attentively the flower which is made by nature. Now we can explain this event as a biologist.

When we were quiet, we didn't think about anything, we didn't pay attention anything. We closed our eyes and lay on the meadow our blood is distributed equally. But when we were watching at the flower this equality is disturbed. Why?

If we want to explain this event we will investigate that in human organism is changed when we were watching flower. Which reason in the human organism is changed? Why?

Our eyes are forced (are commanded) to watch the flower by our nervous system. In eyes' cells metabolism are increasing in this reason this event is happened-if an organ work more strongly it needs extra nourishments. At this time in the cells are happening "burning" processes and in cells fluid environment are decreased. As a result, around the cell's fluid environment are changed because in cell is begun "burning" and cell's inside and outside's density are changed because inside of cell has begun "burning" in this reason inside of the cell fluid environment is decreased and equality is disturbed. Outside of cell fluid environment's density more than inside of the cell fluid environment's density in this reason from the outside of cell fluid environment's fluid flow in cell (we know this property of fluid for a long time-fluid flows from dense place to less dense place) as a result capillary blood vessels' fluid density more than outside of cells' fluid environment and fluid flows from capillary blood vessels to outside of cells then in capillary blood vessels' density is decreased in this reason from the vessels blood flows in capillary blood vessels and etc. So the reason which is created blood circulation (This is motive power) - this power can circulate blood in network of veins. Cells every time suck blood from the vessels but previous level-metabolism must be "burn" after the "burning" cells suck the blood from the vessels to continue itself action. Finally blood circulation is created.

All of the cells' functions in human organism are same-all types of cells take the nourishments from the blood and as a result of metabolism cells create energy for its organ. These processes are happened all of the human organism. Somebody can say that: our organs don't work always very hard for examples if we are watching flower, our feet aren't moving, arms aren't moving. This means that The blood doesn't come these organs?. Of course come.

Simply I want to explain my idea with easiness in this reason I took only one organ actions.

Now we can come heart problem. It is very interesting for me, How had it happened that, people include scientists, doctors, students, pupils and other people have believed that heart pump and sucks blood to network of veins (we can consider that totally length of the distance is network of veins can equal nearly two times equator distance). Why have these peoples believed that heart can pump-suck blood? What is the huge power of source? I say, in heart doesn't have like this motive power and in this reason there aren't any explanations-heart won't be able to cope with it.

Touch upon the problem. As we said if any organ does more action then organ has to take more blood (our faces are blushing for embarrassing).if heart pumps blood then which mechanism does it help? - to pump blood to face. You know heart stand beginning of this huge network of veins and pumps blood in this network of veins. Like this pumping (if we accept that blood is pumped by heart) blood must be distributed equally in network of veins. But far gone nobody can find any mechanism that to approach much blood any organ.

Of course, we can find more people to declare opinion against this

*Corresponding author: Mammadov T, Department of Hematology, Azerbaijan University, Baku, Azerbaijan, Tel: +994 5020004 10; E-mail: mammadovts@gmail.com

Received January 27, 2018; Accepted January 29, 2018; Published January 31 2018

Citation: Mammadov T (2018) New Viewing of Blood Circulation in Human Body. J Blood Lymph 8: 202. doi:10.4172/2165-7831.1000202

Copyright: ( 2018 Mammadov T. This is an open-access article distributed under the terms of the Creative Commons Attribution License, which permits unrestricted use, distribution, and reproduction in any medium, provided the original author and source are credited. 
conception and they demand an explanation. In advance to prevent all of the events I want to say that please show me your idea and please try to explain. Then you will see that there isn't any explanation and can't be-the process is happening as I described!

I consider that I didn't explain whole process although I wrote many things about this problem. (But I came conclusion that if we can learn whole blood circulation we can cure our illnesses and we can enjoy our lives). You know I am not a doctor and not a biologist but I read many natural lifestyle supporters' books and after long thoughts I have come this conclusion. This field's people must be investigate and must be learn this very attentively and must be apply to cure illnesses. 